University of Nebraska - Lincoln

DigitalCommons@University of Nebraska - Lincoln

Faculty Publications, Department of Child, Youth, and Family Studies

Child, Youth, and Family Studies, Department of

$1-1-2007$

\title{
IT TAKES TIME: IMPACTS OF EARLY HEAD START THAT LEAD TO REDUCTIONS IN MATERNAL DEPRESSION TWO YEARS LATER
}

\author{
Rachel Chazan-Cohen \\ U.S. Department of Health and Human Services, Rachel.Cohen@umb.edu \\ Catherine Ayoub \\ Harvard University, catherine.ayoub@childrens.harvard.edu \\ Barbara Alexander Pan \\ Harvard University \\ Lori Roggman \\ Utah State University, lori.roggman@usu.edu \\ Helen Raikes \\ University of Nebraska-Lincoln, hraikes2@unl.edu \\ See next page for additional authors
}

Follow this and additional works at: https://digitalcommons.unl.edu/famconfacpub

Part of the Family, Life Course, and Society Commons

Chazan-Cohen, Rachel; Ayoub, Catherine; Alexander Pan, Barbara; Roggman, Lori; Raikes, Helen; McKelvey, Lorraine; Whiteside-Mansell, Leanne; and Hart, Andrea, "IT TAKES TIME: IMPACTS OF EARLY HEAD START THAT LEAD TO REDUCTIONS IN MATERNAL DEPRESSION TWO YEARS LATER" (2007). Faculty Publications, Department of Child, Youth, and Family Studies. 47.

https://digitalcommons.unl.edu/famconfacpub/47

This Article is brought to you for free and open access by the Child, Youth, and Family Studies, Department of at DigitalCommons@University of Nebraska - Lincoln. It has been accepted for inclusion in Faculty Publications, Department of Child, Youth, and Family Studies by an authorized administrator of DigitalCommons@University of Nebraska - Lincoln. 


\section{Authors}

Rachel Chazan-Cohen, Catherine Ayoub, Barbara Alexander Pan, Lori Roggman, Helen Raikes, Lorraine McKelvey, Leanne Whiteside-Mansell, and Andrea Hart 


\title{
IT TAKES TIME: IMPACTS OF EARLY HEAD START
} THAT LEAD TO REDUCTIONS IN MATERNAL DEPRESSION TWO YEARS LATER

\author{
RACHEL CHAZAN-COHEN \\ U.S. Department of Health and Human Services \\ CATHERINE AYOUB AND BARBARA ALEXANDER PAN \\ Harvard University \\ LORI ROGGMAN \\ Utah State University \\ HELEN RAIKES \\ University of Nebraska-Lincoln

\begin{abstract}
LORRAINE MCKELVEY, LEANNE WHITESIDE-MANSELL, AND ANDREA HART
University of Arkansas
\end{abstract}

\begin{abstract}
The Early Head Start Research and Evaluation Project, a random-assignment evaluation, found a broad pattern of positive impacts for children and families. However, there were no program impacts on depression or use of mental health services by the time children reached age 3 , at the end of the Early Head Start (EHS) program. This paper presents recent findings from the follow-up study in the spring prior to the children entering kindergarten, when a positive program impact emerged for reducing maternal depression. Results show that earlier program impacts on children and parents (when children were 2 and 3 years of age) mediated, or led to, the delayed impact on maternal depression. The combination of the most promising child factors accounted for over $57 \%$ of the later impact on depression, while the most promising parent factors accounted for over $35 \%$ of the later impact on depression. Implications for EHS programs are discussed.
\end{abstract}

RESUMEN: El Proyecto de Investigación y Evaluación de los Programas de Comienzo Temprano (EHS), una evaluación asignada al azar, halló un patrón amplio de impactos positivos para niños y familias. Sin embargo, no se dio ningún impacto del programa en la depresión o en el uso de los servicios de salud mental para cuando los niños alcanzaron la edad de 3 años, al final del Programa de Comienzo Temprano (EHS). Este ensayo presenta recientes resultados del estudio de seguimiento en la primavera anterior a cuando los niños entraron en el kinder, momento en el cual un impacto positivo del programa surgió con la reducción de la depresión maternal. Los resultados muestran que los más tempranos impactos del programa en los niños y sus padres (cuando los niños tenían 2 y 3 años) mediaron, o

Direct correspondence to: Rachel Chazan-Cohen, OPRE/ACF, 370 L’Enfant Promenade SW, Washington, DC 20447; e-mail: rachelcc@gmail.com. The content of this publication does not necessarily reflect the views or policies of the U.S. Department of Health and Human Services.

INFANT MENTAL HEALTH JOURNAL, Vol. 28(2), 151-170 (2007)

(c) 2007 Michigan Association for Infant Mental Health This article is a U.S. government work and, as such, is in the public domain in the United States of America. Published online in Wiley InterScience (www.interscience.wiley.com). DOI: 10.1002/imhj.20127 
sirvieron de pauta para el demorado impacto de la depresión maternal. La combinación de los más prometedores factores en el niño fueron causa del $57 \%$ del futuro impacto en la depresión, mientras que los más prometedores factores en los padres fueron responsables de más del $35 \%$ del futuro impacto en la depresión. Se discuten las implicaciones de los Programas de Comienzo Temprano (EHS).

RÉSUMÉ: Le Projet de Recherche et d'Evaluation du Early Head Start (programme américain d'aide aux familles à faibles revenus), une évaluation au hasard, a fait état d'un modèle large d'impacts positifs pour les enfants et les familles. Cependant, aucun impact de programme n'a été trouvé sur la dépression et l'utilisation des services de santé mentale au moment où les enfants avaient atteint 3 ans, à la fin du programme de Early Head Start. Cet article présente des résultats récents émanant d'une étude de suivi au printemps précédant l'entrée des enfants en maternelle, lorsqu'un impact positif du programme s'est présenté pour la réduction de la dépression maternelle. Les résultats montrent que les impacts précédents du programme sur les enfants et les parents (quand les enfants avaient 2 et 3 ans) influençaient ou menaient à un impact retardé sur la dépression maternelle. La combinaison des facteurs les plus promettants chez l'enfant comptait pour plus de $57 \%$ sur l'impact ultérieur sur la dépression, alors que les facteurs les plus promettants chez le parent comptait pour plus de 35\% sur l'impact ultérieur sur la dépression. Les implications pour les programmes de EHS sont discutées.

ZUSAMMENFASSUNG: Das Forschungs- und Evaluationsprojekt der Frühförderung, eine Evaluation, die eine zufällige Zuordnung verwandte, fand Muster von positiven Auswirkungen auf die Kinder und deren Familien. Jedoch gab es keine Programmpunkte für Depression, oder die Verwendung von Diensten für die seelische Gesundheit bis zum dritten Lebensjahr der Kinder, das Ende der Frühförderung. Diese Arbeit präsentiert kürzlich erworbene Ergebnisse aus der Nachsorgestudie, die im Frühjahr bevor die Kinder den Kindergarten besuchen gemacht wurde und sich positive Auswirkungen auf die mütterliche Depression zeigten. Die Ergebnisse zeigen, dass frühere Programmpunkte im Alter der Kinder von zwei bis drei Jahren die mütterliche Depression milderten, oder zu einer verbessernden Auswirkung auf sie führten. Die Kombination der vielversprechendsten kindlichen Faktoren brachten eine Reduktion bezüglich der späteren Depression um 57\%, während die vielversprechendsten elterlichen Faktoren 35\% der späteren Depression reduzierten. Die Bedeutung für das EHS wird diskutiert.

$$
\begin{aligned}
& \text { 抄録：早期ヘッド・スタート研究と評価ブロジェクト、無作為割り当て評価は、千ども } \\
& \text { と家族に、広範䍏にわたる肯定的な影響パターン在見いだした。しかしながら、子ども } \\
& \text { が3歳に達した洔、早期へッド・スタート・プログラム（EHS）の終了時までには、抑 } \\
& \text { うつあるいは精神保健けービスの利用について、なんのプログラムの影響もなかった。 } \\
& \text { この論文では、子ざもが幼稚園に人る直前の春に行われた追跡研究から、最近の所見を } \\
& \text { 提示する。このとさ、母親の抑らつを減少させるといら肯定的なプログラムの影響が現 } \\
& \text { れていた。結果から、子ビもと両親への（子どもが } 2 、 3 \text { 歳だった時の）早期のブログ } \\
& \text { ラムの影響が、杰親の抑らつに対寸る遅延した影響在媒介した、あるいは尊いたことが } \\
& \text { 示される。最も有望な子どもの因子の組名合わせが、後の抑うつ八の影響の } 57 \% \text { 以上 } \\
& \text { を説明したが、その一方最も有望な親の因子は、後の抑うつへの影響の35\%以上在説 } \\
& \text { 明した。EHSプログラムに対して持つ意味について、議諭される。 } \\
& \text { * * * }
\end{aligned}
$$


This special issue of the Infant Mental Health Journal is devoted to the role that a two-generational comprehensive child development intervention, Early Head Start, can play in supporting the mental health of children and their parents. The Early Head Start Research and Evaluation Project found a high rate of maternal depression, but no program impacts on reducing depression or on families' use of mental health services by the time children reached age 3, at the end of the Early Head Start program. ${ }^{1}$ However, the evaluation did document a pattern of broad benefits for children and families. Especially notable were positive impacts on parenting and the parent-child relationship for those families where mothers were depressed at the time of enrollment (ACF, 2002). So, while Early Head Start did not impact depression directly, there was a change in the parenting context of the depression. These findings, in part, led to the Early Head Start Infant Mental Health initiative, a search for ways for programs to address mental health more directly. This paper presents recent findings from the follow-up study of the Early Head Start Research and Evaluation Project sample in the spring prior to the children entering kindergarten. At this follow-up point, a reduction in depressive symptoms was observed for mothers who had previously participated in Early Head Start. We explore here earlier program impacts that may have mediated or led to the later reduction in maternal depression. Both mother and child factors are considered.

Depression is one of the most common emotional illnesses in the United States today. More than $20 \%$ of Americans will experience a major depressive episode during their lifetimes. Depression is even more prevalent in high-risk populations such as those served by Early Head Start. Studies of families with young children living in poverty report rates for maternal depression at between one quarter to one half of the mothers (Knitzer, 2001; Liaw \& Brooks-Gunn, 1994). Among mothers in the Early Head Start Research and Evaluation Project, over half (58\%) scored above a clinical cutoff of depressive symptoms at the time of enrollment. $^{2}$

Two broad classes of risk factors have been identified as increasing the likelihood of depressive disorder. The first group has to do with living with adversity — experiencing losses, bereavement, and other social stresses. Severe and cumulative psychosocial stressors related to loss can trigger and extend depressive symptoms (Beardslee \& Knitzer, 2003). The second group of risk factors relates to the clustering of mental illness in families. Having multiple relatives with one or more mental illnesses, suggesting a possible genetic link, may also be a predisposing factor (Lieb et al., 2002). In a number of situations, depression results from a combination of these environmental and genetic factors. In this article, we do not address genetic contributions but rather provide information on the role of a supportive intervention as well as the early parent-child relationship for influencing later symptoms of maternal depression.

Given the environmental contributions to depression, a two-generation supportive intervention aimed at improving both child and parent outcomes might expect to have an impact on reducing depressive symptoms. During their child's early years, the mothers in the Early Head Start Research and Evaluation Project sample continued to show high rates of depressive symptoms; 38\% of mothers scored above the clinical cutoff when their child was 14

\footnotetext{
${ }^{1}$ Note that some families left the program before the official end of the program when the child reached age 3 .

${ }^{2}$ Note that in order to be consistent in measurement throughout the longitudinal study, in this article we report on the short form of the CES-D. Percentages will differ from prior reports (ACF, 2001; ACF, 2002), which reported scores on the full scale. Baseline depression data was collected in 8 of the 17 sites.
} 
TABLE 1. Early Head Start Impacts on Maternal Depression

\begin{tabular}{lcccc}
\hline & & & \multicolumn{3}{c}{$\begin{array}{c}\text { Estimated } \\
\text { Impact per } \\
\text { Outcome }\end{array}$} & Program Group & Control Group & Applicant $^{\mathrm{a}}$ & Effect Size $^{\mathrm{b}}$ \\
\hline 14 months average CES-D score & 8.8 & 8.8 & -0.02 & .0 \\
14 months percentage $>=10$ & 38.0 & 37.6 & 0.3 & .01 \\
36 months average CES-D score & 7.6 & 7.8 & -0.2 & -.02 \\
36 months percentage $>=10$ & 31.9 & 31.2 & 0.7 & .01 \\
Pre-K average CES-D score & 7.5 & 8.3 & -0.7 & $-.10^{*}$ \\
Pre-K percentage $>=10$ & 31.0 & 36.0 & -0.04 & $-.09^{*}$ \\
Sample Size & & & & \\
14 month & $\mathbf{1 1 7 5}$ & $\mathbf{1 1 2 5}$ & & \\
36 month & $\mathbf{1 0 9 5}$ & $\mathbf{1 0 0 0}$ & & \\
Pre-Kindergarten & $\mathbf{1 0 5 6}$ & $\mathbf{9 7 6}$ & & \\
\hline
\end{tabular}

NOTE: Note that in order to be consistent in measurement throughout the longitudinal study, in this article we report on the short form of the CES-D. Percentages will differ from prior reports (Administration on Children, Youth and Families, 2001; Administration for Children and Families, 2002), which reported scores on the full scale.

${ }^{a}$ Intent-to-treat analyses are reported here. Per-participant impacts did not differ significantly from intent-to-treat analyses. The estimated impact per eligible applicant is measured as the difference between the regression-adjusted means for all program and control group members. All impact estimates were calculated using regression models, in which each site was weighted equally.

${ }^{\mathrm{b}}$ The effect size was calculated by dividing the estimated impact per participant by the standard deviation of the outcome measure for the control group.

$+p<.10 ;{ }^{*} p<.05 ;{ }^{* *} p<.01$

months old and $32 \%$ when their child was 3 years old (see Table 1). Contrary to expectations, there was no program impact on reducing maternal depression while families were in the program, despite a broad pattern of other positive impacts for children and parents (ACYF, 2001; ACF, 2002). Early Head Start had positive impacts on all of the factors listed in Table 2. However, in a follow-up study approximately 2 years after completion of the program, in the spring before children were entering kindergarten, those mothers who had experienced Early Head Start reported fewer symptoms of depression than those who were in the control group (Love et al., 2005; see also Table 1). This finding begs the question-can this "sleeper effect," an effect that takes some time to become apparent, be linked to earlier program efforts? What is it that programs did earlier that led to this later reduction in depression?

\section{NEGATIVE EFFECTS OF DEPRESSION ON CHILDREN}

A large literature has documented the negative effects of parent depression for children. For example, a number of studies report that children from homes of affectively ill parents are two to four times as likely to develop an affective disorder as are children with non-ill parents (Beardslee, Versage, \& Gladstone, 1998; Pilowsky et al., 2006). Furthermore, children of depressed parents are at increased risk for cognitive and language problems, insecure attachments, difficulties with emotional regulation, social competence, and behavioral problems (Gladstone \& Beardslee, 2002). Much of this literature has presented a unidirectional pattern of influence, from parent to child. Some have talked about the genetic vulnerabilities transmitted from parents, while others have pointed to the mediating influence of mother-child 
TABLE 2. Descriptive Statistics for Selected Variables With Demonstrated Early Head Start Impacts

\begin{tabular}{|c|c|c|c|c|}
\hline Mediators & M & $\mathrm{SD}$ & Possible range & $\mathrm{N}$ \\
\hline \multicolumn{5}{|l|}{ Child Factors } \\
\hline Age 2 aggressive behavior & 12.57 & 6.66 & $0-36$ & 1,688 \\
\hline Age 2 Bayley & 89.05 & 13.77 & 49-139 & 1428 \\
\hline Age 2 Vocabulary & 54.45 & 23.18 & $0-100$ & 1656 \\
\hline Age 3 Child engagement & 4.71 & 1.01 & $1-7$ & 1,411 \\
\hline Age 3 Attention to object & 4.90 & 0.95 & $2-7$ & 1,408 \\
\hline Age 3 Child negativity & 1.26 & 0.56 & $1-7$ & 1,411 \\
\hline Age 3 Aggressive behavior & 11.10 & 6.42 & $0-37$ & 1,693 \\
\hline Age 3 Bayley & 90.79 & 12.64 & $49-134$ & 1,396 \\
\hline Age 3 PPVT & 83.39 & 15.71 & $40-125$ & 1,189 \\
\hline \multicolumn{5}{|l|}{$\begin{array}{c}\text { Parenting/Family } \\
\text { Factors }\end{array}$} \\
\hline Age 2 Family conflict & 1.71 & 0.54 & $1-4$ & 1,490 \\
\hline Age 2 Parenting distress & 25.33 & 9.27 & $12-60$ & 1,707 \\
\hline Age 2 Detachment (video) & 1.45 & 0.89 & $1-7$ & 1,467 \\
\hline Age 2 Supportiveness (video) & 3.97 & 1.03 & $1-6.67$ & 1,467 \\
\hline Age 2 HOME & 26.38 & 3.50 & $8.27-31$ & 1,567 \\
\hline Age 2 Spanking & 0.49 & 0.50 & $0-1$ & 1,698 \\
\hline Age 2 Daily reading & 0.55 & 0.50 & $0-1$ & 1,698 \\
\hline Age 2 Regular bedtime & 0.59 & 0.49 & $0-1$ & 1,730 \\
\hline Age 2 Read At bedtime & 0.26 & 0.44 & $0-1$ & 1,712 \\
\hline Age 3 Detachment (video) & 1.23 & 0.59 & $1-6$ & 1,411 \\
\hline Age 3 supportiveness (video) & 3.93 & 0.93 & $1-6.33$ & 1,410 \\
\hline Age 3 HOME & 27.27 & 4.75 & $10-37$ & 1,527 \\
\hline Age 3 spanking & 0.50 & 0.50 & $0-1$ & 1,686 \\
\hline Age 3 daily reading & 0.54 & 0.50 & $0-1$ & 1,723 \\
\hline
\end{tabular}

NOTE: Statistics were calculated for those subjects with completed prekindergarten ratings of maternal depression, the sample that was used in regression analyses

interactions in the relation between maternal depression and adverse child outcomes. Depression has been associated with problems in parenting, including parental unresponsiveness, unpredictability, and increased hostility. More recently, theorists are also proposing the interrelatedness of parent, child, and environmental factors (Belsky, 1984; Elgar, McGrath, Waschbusch, Stewart, \& Curtis, 2004; Garstein \& Sheeber, 2004; Goodman \& Gotlib, 1999; Granic \& Patterson, 2006; Seifer, Dickstein, \& Sameroff, 2001; Sameroff \& MacKenzie, 2003), suggesting bidirectional influences between parents and children. Thus, child, parent, and parent-child relationship factors contribute to or exacerbate existing pathology, both in the child and the parent. There is some empirical evidence to support these theories (Elgar et al., 2004; Garstein \& Sheeber, 2004). Interestingly, most of the empirical literature on child contributions focuses on negative or challenging aspects of child behavior, including difficult temperament and behavior problems (e.g., Cutrona \& Troutman, 1986; Elgar et al., 2004; Garstein \& Sheeber, 2004; Gelfand, Teti, \& Fox, 1992; Seifer et al., 2001).

A recent example is Granic and Patterson (2006), who propose a dynamic systems ap- 
TABLE 3. Comparison of the Baseline Characteristics of Program and Control Group Members

\begin{tabular}{|c|c|c|c|}
\hline Variable & Program Group & Control Group & $p$ \\
\hline \multicolumn{4}{|l|}{ Family and Primary Caregiver Characteristics } \\
\hline Age of Mother at Birth of Focus Child & & & .803 \\
\hline Younger than 20 & 39.0 & 39.5 & \\
\hline 20 to 25 & 33.2 & 32.0 & \\
\hline 25 or older & 27.9 & 28.5 & \\
\hline Highest Grade Completed & & & .175 \\
\hline Less than 12 th grade & 47.7 & 47.8 & \\
\hline 12th grade or earned a GED & 27.3 & 29.8 & \\
\hline More than 12 th grade & 24.9 & 22.4 & \\
\hline Race and Ethnicity & & & .968 \\
\hline White non-Hispanic & 37.3 & 37.1 & \\
\hline Black non-Hispanic & 34.2 & 35.0 & \\
\hline Hispanic & 23.8 & 23.4 & \\
\hline Other & 4.7 & 4.5 & \\
\hline Primary Occupation & & & .826 \\
\hline Employed & 22.9 & 23.8 & \\
\hline In school or a training program & 22.0 & 21.4 & \\
\hline Neither employed nor in school or training & 55.0 & 54.7 & \\
\hline English Language Ability & & & .485 \\
\hline Primary language is English & 79.9 & 78.1 & \\
\hline $\begin{array}{l}\text { Primary language is not English, but the applicant } \\
\text { speaks English well }\end{array}$ & 9.6 & 10.3 & \\
\hline $\begin{array}{l}\text { Primary language is not English, and the applicant } \\
\text { does not speak English well }\end{array}$ & 10.5 & 11.6 & \\
\hline Living Arrangements & & & .762 \\
\hline Living with a spouse & 24.9 & 25.4 & \\
\hline Living with other adults & 38.3 & 39.1 & \\
\hline Living with no other adults & 36.8 & 35.5 & \\
\hline \multicolumn{4}{|l|}{ Welfare Receipt } \\
\hline AFDC/TANF & 35.6 & 34.7 & .627 \\
\hline Food stamps & 48.0 & 47.8 & .889 \\
\hline Medicaid & 76.6 & 74.7 & .217 \\
\hline SSI & 7.0 & 7.0 & .978 \\
\hline WIC & 87.5 & 85.9 & .235 \\
\hline Public housing & 9.5 & 8.9 & .565 \\
\hline \multicolumn{4}{|l|}{ Maternal Depression } \\
\hline Total score & 11.75 & 12.02 & .497 \\
\hline$\%$ above cutoff $>=10$ & 57.2 & 58.1 & .739 \\
\hline \multicolumn{4}{|l|}{ Characteristics of Focus Child } \\
\hline Age (Months) & & & .330 \\
\hline Unborn & 24.2 & 26.5 & \\
\hline Less than 5 & 36.1 & 34.7 & \\
\hline 5 or more & 39.7 & 38.7 & \\
\hline Male & 51.7 & 50.4 & .493 \\
\hline First Born & 62.3 & 62.8 & .783 \\
\hline
\end{tabular}


TABLE 3. (Continued.)

\begin{tabular}{|c|c|c|c|}
\hline Variable & Program Group & Control Group & $p$ \\
\hline Birth Weight Less Than 2,500 Grams ${ }^{\mathrm{b}}$ & 9.9 & 8.4 & .237 \\
\hline Covered by Health Insurance ${ }^{b}$ & 90.1 & 89.6 & .723 \\
\hline Sample Size & 1,513 & 1,488 & \\
\hline
\end{tabular}

SOURCE: Head Start Family Information System application and enrollment forms completed prior to random assignment. ${ }^{a}$ Depression data was collected at baseline in 8 of the 17 sites. Total $N=1272$, Program $=650$ and Control $=622$. + Significantly different from zero at the .10 level, two-tailed test.

${ }^{\mathrm{b}}$ These variables pertain to families with focus children who were born at baseline.

proach for understanding early onset antisocial trajectories in children. Their model illuminates possible pathways for intervention effects. Granic and Patterson posit that characteristics of both the child and parent (genetic factors as well as acquired beliefs) can place a dyad at particular risk for adverse outcomes. In the context of additional risk factors such as poverty or life stress, coercive interactions can become rigid stable patterns. It is this stabilization or rigidity that leads over time to pathology. The authors did, in fact, find that children who were rated as highly antisocial by their kindergarten teachers engaged in more rigid interactions with their parents across settings. Moreover, the links between early rigidity and a child's antisocial behavior grew over time.

Developmental timing is also important in predicting negative trajectories. For instance, Granic and Patterson discuss how the peaking of oppositional behavior seen at age 2 (Tremblay et al., 1999) can be a developmental transition point. What for some might seem normative behavior, if paired with sufficient constraints (such as maternal depression) can lead to the development of coercive interactions (either hostile or permissive) that become rigidified over time and lead to adverse outcomes. They also identify ages $3-5$ as being a phase transition for children, both experientially, as they move from the family environment to more institutionalized settings, and cognitively, as they develop the abilities to better understand the perspectives and intentions of others. If the child has rigid patterns of behavior and expectations as he or she undergoes this transition, the child may be at increased risk for negative outcomes. Thus, the timing of intervention is critical. If a maladaptive system can be disrupted at a critical juncture, and children and parents can be provided a wider behavioral repertoire, the system will be less likely to become rigidified. Such an intervention can have lasting and pervasive effects. According to this model, treatment effects may only become evident when the system becomes more flexible following a phase transition. While Granic and Patterson (2006) used their theory to understand child outcomes, the theory can also be used to understand parent outcomes as well.

This systems approach to thinking about linkages between maternal and child well-being has many implications for intervention. As noted, the timing of interventions is important, as is the timing of the assessment of treatment effects. Granic and Patterson (2006) hypothesize that some treatment effects may not emerge until after another phase transition has been experienced. Indeed, in many mental-health intervention studies, stronger impacts are often evident in follow-up studies that were not evident at post-test, suggesting that treatment effects took additional time to emerge and that long-term follow-up studies are important for understanding the potential for interventions to reduce mental health problems (Greenberg, 
Domitrovich, \& Bumbarger, 2001). Furthermore, Granic and Patterson's model would hypothesize that having an effect on any part of the system would lead to effects on other parts of the system. Thus, for instance, the theory would predict that if depressed mothers undergo a successful intervention aimed at ameliorating depression, their children's level of pathology would be affected. This was indeed found in a recent study, where remission of maternal depression after three months of medication treatment was associated with an $11 \%$ reduction of children's psychiatric diagnosis, while children of mothers whose depression did not remit had an $8 \%$ increase in rates of psychiatric diagnosis (Weissman et al., 2006).

The question to be addressed in this paper is: If an intervention improves parenting, parent-child relationship, and child behavior, do these impacts, over time, lead to improvements in parent well-being? It stands to reason that two-generational programs that support positive mother-child interactions would buffer the child's developmental risk and that both of these would lead to better parent well-being over time. Are earlier impacts on both children and parents leading to this later parent well-being? We have the following research predictions:

1. Earlier impacts of Early Head Start on both child and parent factors will account for later impacts on maternal depression. Because the program had positive impacts at both ages 2 and 3, we predict that earlier changes in parents will mediate the program's impact on reduced depression. We also hypothesize that increased developmental competence and reduced negative behavior in children will mediate the program's impact on reductions in depression.

2. The literature on depression primarily documents the risk bestowed by negative factors (e.g., difficult child temperament, family conflict, and life stress). Therefore, we predict that the earlier reduction of negative factors will be more influential as mediators than the earlier increase of positive factors.

3. Finally, given the salience of child oppositional and negative behavior at age 2 for mothers experiencing depression, we expect that the impacts at age 2 will be more influential as mediators than impacts at age 3 , consistent with the systems approach of Granic and Patterson (2006).

\section{METHODS}

\section{Participants and Procedures}

Seventeen Early Head Start programs out of the first 68 programs funded ${ }^{3}$ were selected to participate in the national study. Sites were selected to achieve national geographic distribution, representation of major programmatic approaches and settings, as well as diversity of family characteristics typical of Early Head Start families nationally. Sites were also selected on the basis of the strength of the local research team.

\footnotetext{
${ }^{3}$ Forty-one university research-program partner teams submitted proposals to participate in the research. Programs agreed to randomly assign children to a control group and also agreed to enroll children before 12 months of age only. Outside of the research, children can be enrolled in Early Head Start up to age 3, although programs are encouraged to enroll children in early infancy or in the prenatal period.
} 
The 17 research programs recruited 3,001 families to participate in the evaluation. Except for recruiting twice as many families as they could serve and only recruiting children under the age of 1, programs were expected to recruit the same way they would have done in the absence of the research, with special instructions to include all types of families they were designed to serve (including those whose babies had disabilities). Although programs could apply to have families excused from participating in the research, no exemptions were requested.

Children and families were randomly assigned to the program or control group by the national contractor, Mathematica Policy Research. Control group families did not receive Early Head Start services but could access other services in the community.

Sample enrollment, baseline data collection, and random assignment began in July 1996 and were completed in September 1998. Program staff collected baseline data from all families during the application and enrollment process, before randomization. Random assignment yielded equivalent groups, as seen in the highly similar baseline characteristics of program and control group members (Table 3).

\section{Sample Characteristics}

Primary caregivers of the focus children (mothers in $99 \%$ of the families) and families were diverse (see Table 3 for both family and child characteristics for the entire sample at baseline). Among families assigned to the Early Head Start group, $24 \%$ of the program mothers were pregnant at enrollment; $39 \%$ of mothers were under 20 years old, $33 \%$ were 20 to 25 , and $28 \%$ were older than $25 ; 62 \%$ of children were firstborn; $48 \%$ of mothers had less than a 12th-grade education; 37\% were White non-Hispanic, 34\% African American non-Hispanic, 24\% Hispanic, and 5\% from other backgrounds; 20\% spoke a language other than English; and 36\% were receiving Temporary Assistance to Needy Families (TANF), formerly Aid to Families with Dependent Children (AFDC), at the time of program enrollment.

\section{Response Rates Response Rates}

Sample size varied across waves of data collection and across measures, as shown in Table 2, with somewhat smaller $n$ 's for direct child assessments and videotaped parent-child interactions than for interview measures. The response rate was $72 \%$ for the age 2 parent interview, $59 \%$ for the age 2 direct child assessment, $70 \%$ for the age 3 parent interview, 55\% for the age 3 direct child assessments, and 69\% for the prekindergarten parent interview. Overall, at all time points, response rates were similar for program and control groups. To test for attrition bias, we compared the follow-up samples on their baseline characteristics. Responders were more likely to have been employed, married or living with another adult, not receiving cash assistance, or higher educated. However, we found very few differences between the program and control group responders on baseline characteristics; in estimating program impacts, regression was used to adjust for the any differences that were observed in program-control baseline characteristics. 


\section{Program Characteristics}

Program approaches to service delivery, as specified in the Head Start performance standards, were chosen by grantees to meet the needs of the particular communities and the low-income families they served. The 17 research programs included four center-based programs that provided child development services mainly in center-based child care along with parenting education and a minimum of two home visits a year to each family; seven home-based programs that provided child development services to families mainly through weekly home visits and at least two parent-child group socialization activities a month for each family; and six mixed-approach programs that provided home-based or center-based services, either to different families or in combination to families either simultaneously or at different times.

\section{Data Collection and Measures}

Data were gathered by data collectors centrally trained and certified as reliable. Data collectors and coders of videotaped parent-child interactions were not informed of families' program status. Families were contacted when children were 14, 24, and 36 months old, and again in the spring before they were eligible to enter kindergarten, approximately 2 years after the end of Early Head Start services for children in the program.

We report findings for the primary measures of maternal depression, child development, parenting, and family well-being. These include measures of cognitive and language development, child social-emotional development, parenting behaviors, and parent well-being. Table 2 presents descriptive statistics for each of the measures. We only present measures on which Early Head Start had an impact.

Maternal depression. Maternal depression was assessed at entry to the study (at 8 out of the 17 sites), at child ages 14 and 36 months, and again at the prekindergarten data collection, using the Center for Epidemiologic Studies Depression Scale (CES-D). The full form was used at the time of entry into the study, at 14 and at 36 months, but the short form was used at kindergarten entry. In order to use consistent measurement, in this article we report on the short form of the CES-D (CES-D-SF; Ross, Mirowsky, \& Huber, 1983) at all time points. The CES-D-SF measures self-reported symptoms of depression. It does not indicate a diagnosis of clinical depression, but it does discriminate between depressed patients and others. The short form scale includes 12 items taken from the full, 20-item CESD scale (Radloff, 1977). Respondents were asked the number of days in the past week they had a particular symptom. Symptoms include poor appetite, restless sleep, loneliness, sadness, and lack of energy. Items were coded on a 4-point scale from rarely (0) to most days (3). Scores on the scale range from 0 to 36 . Scores of greater than or equal to 10 indicate the cutoff for possible depression.

Child cognitive and language development. At age 2 and 3, children were assessed using the Mental Development Index (MDI) from the Bayley Scales of Infant Development, 2nd edition (Bayley, 1993). At age 2, vocabulary was assessed by parent report on the MacArthur Communicative Development Inventories Short Form (CDI; Fenson et al., 2000). Parents indicated what words their child produced from a list of 100 words; this form yielded a measure of vocabulary production. At age 3, children's receptive vocabulary was assessed using the Peabody Picture Vocabulary Test, 3rd Edition (PPVT-III; Dunn \& Dunn, 1997). 
Child social-emotional development. The 19-item aggressive behavior subscale of the Child Behavior Checklist (CBCL), adopted from the Achenbach System of Empirically Based Assessment, provided parent ratings of children's aggressive behavior problems (Achenbach \& Rescorla, 2000) at ages 2 and 3.

Observational measures at both ages were obtained from videotaped parent-child interactions in a semistructured play task, adapted for this evaluation from the Three Box coding scales used in the National Institute of Child Health and Human Development (NICHD) Study of Early Child Care (NICHD Early Child Care Research Network, 1997). The play task consisted of a 10-minute session in which the mother was presented with three cloth bags of toys and invited to play with her child however the child wished; the only request was that she use the three bags in the specified order. Instructions were deliberately vague to elicit naturally occurring behaviors and did not specify what language dyads should use. Videotapes of dyads interacting in either English or Spanish were coded by an observer fluent in the language used and are represented in the data reported here. At ages 2 and 3, three aspects of children's videotaped behavior were coded on a 7-point scale: (1) sustained attention with objects (the duration and quality of the child's exploring and playing with toys), (2) engagement of parent (extent to which the child interacts with the parent and communicates positive regard or affect), and (3) child negativity.

Parenting. Two aspects of parenting were assessed, including parent-child interaction and home environment.

Parenting coded from videotapes of parent-child play. We report on two factors, parental supportiveness (a composite of parent warmth, sensitivity, and cognitive stimulation) and parent detachment (the degree to which the parent is emotionally unavailable during play).

Parenting-Home environment. Three measures of the home environment were used at age 2 and 3.The total score from the Home Observation for Measurement of the Environment (HOME) measures the quality of stimulation and support available to a child in the home environment (Caldwell \& Bradley, 1984; Fuligni, Han, \& Brooks-Gunn, 2004). The measure "reads to child daily" is a parent self-report of whether the parent reads to the child "every day" or "more than once a day" versus three categories of less often. The measure "spanked child last week" is a parent self-report of physical punishment during the previous week. In addition, at age 2, parents were asked about daily routines including regular bedtime and reading at bedtime.

Family well-being. Parenting stress and family conflict were both assessed at ages 2 and 3 . Two subscales from the Parenting Stress Index-Short Form (PSI-SF; Abidin, 1983) were administered when children were ages 2 and 3, Parental Distress and Parent-Child Dysfunctional Interaction. Each item is rated on a 5-point scale, with 1 as "strongly disagree" and 5 as "strongly agree." The Parental Distress subscale assesses maternal perception of child-rearing competence, conflict with her spouse or partner, social support, and stresses due to restrictions in other life roles. The Parent-Child Dysfunctional Interaction subscale assesses the extent to which a parent perceives that her child does not meet expectations, and that interactions with the child are not rewarding. Exposure to family conflict was assessed using five items from the conflict subscale of the Family Environment Scale (FES; Moos \& Moos, 1984). The five items related to conflict in the current study include reporting that people in the family fight 
a lot, lose their tempers, throw things, criticize each other, and hit each other.

\section{Analytic Approach}

Regression mediation analyses were conducted to test whether Early Head Start impacts on children and parents at ages 2 and 3 accounted for some of the later Early Head Start impact on maternal depression at prekindergarten. It is important to point out that the analysis asked whether the earlier impacts on children and parents mediated the later impact on mothers' depressive symptoms. That is, it specifically addressed whether the difference between the program and control group at ages 2 and 3 (attributed to the program as a result of the experimental design) could account for the significant differences found between program and control group parents at prekindergarten.

Identifying and testing mediator variables requires a logical series of analyses, first, to test the impact of the program on the outcome (maternal depression at prekindergarten); second, to test the impact of the program on the potential mediator variables; third, to test the association of the potential mediator variables with the outcome; and finally, to test the mediation. Mediation is tested by including both program status and the potential mediators in the same model and then testing, by the Sobel test (1982), whether the impact of the program is substantially reduced by the inclusion of the mediator in the model. Previous analyses established that Early Head Start did have an impact on maternal depression at prekindergarten (Table 1) and also had an impact on several earlier parent and child variables that were logical potential mediators (Table 2) (ACYF, 2001; ACF, 2002).

Mediation analyses were conducted in the following stages to determine the portion of the Early Head Start impact on maternal depression at prekindergarten explained by the impact of Early Head Start on the age 2 and 3 child and parent outcomes. First, using ordinary least squares, each of the mediators and a set of control variables ${ }^{4}$ predicted maternal depression in a series of regression models. The coefficient of the mediator represents the relation of the mediator to maternal depression. Then, the significance of the mediation was tested using the Sobel method (Preacher \& Leonardelli, 2001). In the final stage, for those mediators found to be significant by the Sobel test, the coefficient of the mediator on the outcome from the mediation model was multiplied by the impact of Early Head Start on the mediator and then divided by the impact on maternal depression to determine the portion of the impact on maternal depression that can be attributed to impact on the mediator. We looked first at each mediator separately, then at the proportion of Early Head Start program impact accounted for by sets of significant family mediators, and then, finally, at the proportion of impact accounted for by sets of significant child mediators.

\footnotetext{
${ }^{4}$ We included a large number of control variables in the regression models. These variables were constructed using Head Start Family Information System and pertain to characteristics and experiences of families and children prior to random assignment. The variables were: age of mother, race, language spoken in the home, maternal education, maternal occupation, living arrangements, number of children in the household, poverty level, welfare receipt (AFDC/TANF; Food Stamps; WIC; SSI), adequacy of resources (food, housing, money, medical care, transportation), previously enrolled in Head Start or other child development program, mobility in the previous year, random assignment date, age of child, birth weight less than 2,500 grams, gestational age, gender, and child risk status (established, biological/medical, environmental).
} 
TABLE 4. Parenting and Family Mediators-Contribution of Each Separately

\begin{tabular}{|c|c|c|c|}
\hline $\begin{array}{l}\text { Mediator } \\
\text { Parenting/Family Factors }\end{array}$ & $\begin{array}{c}\text { Estimated Effect } \\
\text { of Mediator on } \\
\text { Maternal } \\
\text { Depression at } \\
\text { PreK }\end{array}$ & $\begin{array}{l}\text { Sobel Test of } \\
\text { Significance of } \\
\text { Mediator }\end{array}$ & $\begin{array}{c}\text { Percent of EHS } \\
\text { Impact on Maternal } \\
\text { Depression at PreK } \\
\text { Associated with } \\
\text { Mediator }\end{array}$ \\
\hline Age 2 family conflict & $2.40^{* * *}$ & $-1.74+$ & 17.4 \\
\hline Age 2 parenting distress & $.19^{* * * *}$ & $-2.30^{*}$ & 29.1 \\
\hline Age 2 detachment (video) & Ns & Ns & \\
\hline Age 2 supportiveness (video) & $-.52^{* *}$ & $-2.01^{*}$ & 11.7 \\
\hline Age 2 HOME & $-.18^{* *}$ & $-1.98^{*}$ & 10.6 \\
\hline Age 2 spanking & $.82^{*}$ & $-1.73+$ & 7.3 \\
\hline Age 2 daily reading & $-.88^{*}$ & $-1.71+$ & 7.1 \\
\hline Age 2 regular bedtime & $-.88^{*}$ & Ns & \\
\hline Age 2 read at bedtime & $-.87^{*}$ & $-1.74+$ & 8.4 \\
\hline Age 3 detachment (video) & $.70^{*}$ & Ns & \\
\hline Age 3 supportiveness (video) & Ns & Ns & \\
\hline Age 3 HOME & $-.18^{* * *}$ & $-2.06^{*}$ & 14.0 \\
\hline Age 3 spanking & $.87^{*}$ & $-1.92^{+}$ & 9.3 \\
\hline Age 3 daily reading & $-.86^{*}$ & Ns & \\
\hline
\end{tabular}

$+p<.10 ;{ }^{*} p<.05 ;{ }^{* *} p<.01 ;{ }^{* * *} p .001$

\section{RESULTS}

As noted previously, at the prekindergarten follow-up - 2 years after the end of the programfor the first time there was an impact of Early Head Start on reducing maternal depression. While statistically significant, the impact was modest in size, effect size $=0.10$. Those mothers assigned to the Early Head Start group had an average score of 7.5 on the CES-D, while mothers assigned to the control group had an average score of 8.3 (Table 1). The results below explore which of the impacts Early Head Start had on children and families at age 2 and 3 (Table 2) lead to the reduction in maternal depression at prekindergarten. We also show what proportion of the impact can be attributed to the mediating factors.

\section{Contribution of Individual Parent/Family Mediators}

As shown in Table 4, of the nine family factors at age 2 where Early Head Start had an impact, all but one, parent detachment during play, were significantly associated with maternal depression at prekindergarten. Sobel tests revealed seven significant mediators: family conflict accounted for $17.4 \%$ of the later impact on maternal depression at prekindergarten; parenting distress $29.1 \%$; maternal supportiveness during play $11.7 \%$; home environment $10.6 \%$; spanking $7.3 \%$; daily reading $7.1 \%$; and reading at bedtime $8.4 \%$.

Of the five family factors at age 3 where Early Head Start had an impact, all but one, parent supportiveness during play, were significantly associated with later maternal depression. However, Sobel tests revealed only two significant mediators: home environment accounted for $14 \%$ of the later impact on maternal depression, and spanking 9.3\%. 
TABLE 5. Child Mediators-Contribution of Each Separately

\begin{tabular}{lccc}
\hline Mediator & $\begin{array}{c}\text { Estimated Effect of } \\
\text { Mediator on Maternal } \\
\text { Depression at PreK }\end{array}$ & $\begin{array}{c}\text { Sobel Test of } \\
\text { Significance of } \\
\text { Mediator }\end{array}$ & $\begin{array}{c}\text { Percent of EHS Impact on } \\
\text { Maternal Depression at } \\
\text { PreK Associated with } \\
\text { Mediator }\end{array}$ \\
\hline Age 2 aggressive behavior & $.20^{* * *}$ & $-2.06^{*}$ & 20.4 \\
Age 2 Bayley & $-.03^{*}$ & $-1.6+$ & 8.5 \\
Age 2 Vocabulary & $-.02^{*}$ & $-1.6+$ & 8.1 \\
Age 3 child engagement & $-.43^{*}$ & $-1.8+$ & 11.1 \\
Age 3 attention to object & Ns & Ns & 12.3 \\
Age 3 child negativity & $1.12^{* * *}$ & $-1.97^{*}$ & 20.5 \\
Age 3 aggressive behavior & $.27^{* * *}$ & $-2.41^{*}$ & 11.9 \\
Age 3 Bayley & $-.05^{* *}$ & $-1.92+$ & 12.1 \\
Age 3 PPVT & $-.05^{* *}$ & $-1.66+$ & \\
\hline
\end{tabular}

$+p<.10 ;{ }^{*} p<.05 ;{ }^{* *} p<.01 ;{ }^{* * *} p<.001$

\section{Contribution of Individual Child Mediators}

As shown in Table 5, all three child factors at age 2 on which Early Head Start had an impact were significantly associated with maternal depression at prekindergarten. Sobel tests revealed that all three were significant mediators: aggressive behavior accounted for $20.4 \%$ of the later impact on maternal depression at prekindergarten; Bayley mental development index, 8.5\%; and CDI vocabulary, $8.1 \%$.

Of the six child factors at age 3 where Early Head Start had an impact, all but one, child attention to objects during play, were significantly associated with later maternal depression. Sobel tests revealed that all five were significant mediators: child engagement during play accounted for $11.1 \%$ of the later impact on maternal depression; child negativity during play, 12.3\%; aggressive behavior, 20.5\%; Bayley MDI, 11.9\%; and PPVT vocabulary, $12.1 \%$.

\section{Cumulative Contribution of Age 2 and Age 3 Family Mediators}

As shown in Table 6, 35.5\% of the impact of Early Head Start on prekindergarten maternal depression (difference between the program and control group) was significantly mediated by earlier impacts on a combination of two parenting variables when children were 2 and 3 years old, as indicated by the Sobel test: age 2 parenting distress accounted for 26\%; and age 2 spanking, 9.5\%. Due to suppression effects, HOME scores and parent supportiveness during play from the same assessment point were not entered together. Thus, age 2 HOME score was not included in the model.

\section{Cumulative Contribution of Age 2 and Age 3 Child Mediators}

As shown in Table 7, 57.7\% of the impact of Early Head Start on prekindergarten maternal depression (difference between the program and control group) was significantly mediated by earlier impacts on child variables when children were age 2 and 3, as indicated by the Sobel 
TABLE 6. Most Promising Age 2 and 3 Parenting and Family Mediators

\begin{tabular}{lccc}
\hline $\begin{array}{l}\text { Mediator } \\
\text { Parenting/Family Factors }\end{array}$ & $\begin{array}{c}\text { Estimated Effect of } \\
\text { Mediator on Maternal } \\
\text { Depression at PreK }\end{array}$ & $\begin{array}{c}\text { Sobel Test of } \\
\text { Significance of } \\
\text { Mediator }\end{array}$ & $\begin{array}{c}\text { Percent of EHS Impact on } \\
\text { Maternal Depression at PreK } \\
\text { Associated with Mediator }\end{array}$ \\
\hline Age 2 family conflict & $1.58^{* * *}$ & $\mathrm{Ns}$ & \\
Age 2 parenting distress & $.17^{* * *}$ & $-2.22^{*}$ & 26.0 \\
Age 2 supportiveness during play & $\mathrm{Ns}$ & $\mathrm{Ns}$ & \\
Age 2 spanking & $1.07^{*}$ & $-1.71+$ & \\
Age 2 daily reading & $\mathrm{Ns}$ & $\mathrm{Ns}$ & \\
Age 3 HOME & $\mathrm{Ns}$ & $\mathrm{Ns}$ & \\
Age 3 spanking & $\mathrm{Ns}$ & $\mathrm{Ns}$ & \\
TOTAL & & & 35.5 \\
\hline
\end{tabular}

Taken together, these factors accounted for $35.5 \%$ of the impact on maternal depression $(\mathrm{N}=1002)$.

NOTE: Individual family mediators with Sobel test significant at $<.10$. were included, except for age 2 HOME scores. Parent supportiveness and HOME scores from same time period create suppression effects when entered into the model concurrently. $+p<.10 ;{ }^{*} p<.05 ;{ }^{* *} p<.01 ;{ }^{* * *} p .001$

test: age 2 aggression accounted for 16.3\%; age 3 aggression, 22.4\%; and age 3 Bayley, $19 \%$. Note that if more than one factor from the same measure met criteria for inclusion, the stronger mediator was chosen. In this case, both child engagement and child negativity during play at age 3 were significant mediators, but child negativity was retained in the model.

\section{DISCUSSION}

As hypothesized, Early Head Start impacts when children were 2 and 3 years of age mediated the delayed impact of Early Head Start on maternal depression when children were about to enter kindergarten. These results show that the earlier impacts on parents and children did

TABLE 7. Most Promising Age 2 and 3 Child Mediators

\begin{tabular}{|c|c|c|c|}
\hline $\begin{array}{l}\text { Mediator } \\
\text { Child Factors }\end{array}$ & $\begin{array}{c}\text { Estimated Effect of Mediator } \\
\text { on Maternal Depression at } \\
\text { PreK }\end{array}$ & $\begin{array}{l}\text { Sobel Test of } \\
\text { Significance of } \\
\text { Mediator }\end{array}$ & $\begin{array}{c}\text { Percent of EHS Impact on } \\
\text { Maternal Depression at PreK } \\
\text { Associated with Mediator }\end{array}$ \\
\hline Age 2 aggressive behavior & $.16^{* * *}$ & $-1.82+$ & 16.3 \\
\hline Age 2 MacArthur vocabulary & Ns & Ns & \\
\hline Age 2 Bayley MDI & $.04+$ & Ns & \\
\hline Age 3 negativity during play & $.83+$ & Ns & \\
\hline Age 3 aggressive behavior & $.18^{* * *}$ & $-2.07^{*}$ & 22.4 \\
\hline Age 3 Bayley MDI & $-.08^{* *}$ & $-1.87+$ & 19.0 \\
\hline Age 3 PPVT vocabulary & Ns & Ns & \\
\hline TOTAL & & & 57.7 \\
\hline
\end{tabular}


lead to the emergence of an impact on maternal depression 2 or more years later. Both child factors and family factors mediated the later impact on depression. The combination of the most promising child factors accounted for over $57 \%$ of the later impact on depression, while the most promising parent factors accounted for over 35\% of the later impact on depression. The importance of child factors is somewhat surprising, as it might be more intuitive to think that program impacts on reductions in family stress and more positive parenting might be the most likely pathways to later maternal well-being. However, child behaviors and abilities do contribute to or exacerbate later depression, as shown in this study and others (Cutrona \& Troutman, 1986; Elgar et al., 2004; Garstein \& Sheeber, 2004; Seifer et al., 2001), and conversely, interventions that improve child outcomes appear to have an indirect effect on maternal well-being as well. These findings highlight the importance of focusing on child development within supportive interventions.

A range of family factors was identified as mediators of the impact on maternal depression, including both positive and negative factors. Positive factors included maternal supportiveness during play, support for learning and development in the home environment, daily reading and reading at bedtime, all assessed at age 2, as well as support for learning and development in the home environment observed at age 3. Negative family factors identified as mediators included family conflict, parenting stress, and parent report of physical punishment at age 2, as well as parent report of physical punishment at age 3 . When all of the significant family mediators are taken into account together, the two remaining significant factors are parenting distress and spanking at age 2, both of which are negative factors reduced by the Early Head Start program.

The primacy of negative parenting at age 2 for later well-being in some ways confirms the mythology of the "Terrible Twos" as a time when some parents have trouble managing children's normally developing drive for individuation. As children move from infancy into toddlerhood with a growing sense of autonomy, how parents cope with this period determines, at least in part, later parent functioning. Our findings provide one indicator of the critical importance of this early transition for both children and their parents. Parent report of physical punishment, spanking, is an especially interesting behavior and may reflect a limited repertoire of dealing with children's negative behavior. The associations of spanking with later maternal depression support the negative outcomes of a rigid punitive cyclical style discussed by Patterson (2002).

Similarly, for child factors, both positive and negative factors were identified as significant mediators of the impact on maternal depression. Positive behaviors or abilities included cognition and vocabulary at both ages 2 and 3 as well as child engagement with parent during play at age 3. Negative factors included parent report of aggressive behavior at ages 2 and 3 as well as child negativity toward parent during play at age 3 . When all of the significant child mediators are combined, only three remain significant: aggression at ages 2 and 3, and cognitive functioning at age 3 . While child aggression is clearly very salient in terms of parent well-being, and echoes the linkages between child difficult temperament and maternal depression (Cutrona \& Troutman, 1986; Elgar et al., 2004; Garstein \& Sheeber, 2004; Gelfand et al., 1992), children's vocabulary and cognitive abilities were also important mediators of maternal depression.

Upon reflection, the skills tapped in the Bayley scales of development at age 3, such as the ability to communicate clearly and the ability to understand another's perspective would certainly influence the experience of parenting and thus parent well-being. It is no doubt much 
easier to parent a communicative child who would have a broader range of skills and abilities to bring to interactions than to parent a child with limited communication skills. Of course, children's language abilities at age 3 themselves have developed in the context of patterns of parent-child communicative interactions over the first three years of life (Pan, Rowe, Singer, $\&$ Snow, 2005). The results of the current study suggest that by age 3 , those language and cognitive abilities have come to function as important protective factors for the parent-child relationship and parent well-being. This is the key protective factor, in contrast to the risk factors, identified in this study.

So, while for parents it appears that the hypothesis of negative factors being more salient for maternal depression is somewhat borne out, for child factors both negative behavior and child cognitive abilities were salient. Furthermore, as noted above, earlier impacts at both ages 2 and 3 were significant mediators of the later impact on maternal depression, but the important age differed for family and child factors. For family mediators, age 2 seemed more influential, while for child mediators, age 3 factors were more influential. Altogether, the findings lend support for the dynamic systems approach suggested by Granic and Patterson (2006), and for the recommendation to test delayed outcomes to avoid underestimating program effects (Greenberg et al., 2001). Furthermore, the findings of this study demonstrate that far more research is needed to understand the developmental aspects of parent and child trajectories in the context of poverty, intervention, and mental health.

Several limitations caution us in the interpretation of these findings. First, several of the significant mediators, including child aggression, parent physical punishment, activities in the home (i.e., daily reading and reading at bedtime), family conflict, and parenting distress are parent self-report, as is the report of depressive symptoms. The shared reporter may influence the strength of the findings. However, not all of the significant mediators are parent report, most notably parent-child play and the home environment, which were rated by trained observers, as well as assessments of child vocabulary at age 3 and child cognitive abilities at age 2 and 3, which were directly tested by trained assessors. Another limitation is the somewhat small sample size due to attrition and missing data, given the longitudinal nature of the study. This may have led us to underestimate the significance of some mediating factors.

There are several take-away messages for Early Head Start programs. First, while having the strength-based approach embraced by Early Head Start is helpful in working with families, some attention needs to be focused on negative family experiences in order to have this broader impact on mothers' well-being. Being strength-based while acknowledging the risks and difficulties faced by families is the key (Beardslee \& Knitzer, 2003). As program staff have long believed, focusing on relationships does translate, down the line, to reducing depression. But more can be done. Linking families with mental health services and other approaches as described in other articles in this special issue can lead to a reduction in depression sooner. Our findings also support the child development focus within the twogenerational approach offered by Early Head Start. The earlier impacts on children are the strongest mediators of the later reduction in depression. So, while a focus on parents is not wrong, programs must also focus on the child, specifically child abilities and communication. Either alone is not enough.

In conclusion, Early Head Start, a child development and family focused program, does have an impact on reducing depression 2 years after the program ends. Earlier impacts on both children and parents lead to this later impact. Therefore, entering the system and im- 
proving parenting, the family context, or the child's development can influence maternal depression over time. In order to address families' mental health needs in a more timely way, targeted interventions are needed.

\section{AUTHORS' NOTE}

The findings reported here are based on research conducted as part of the national Early Head Start Research and Evaluation Project funded by the Administration for Children and Families (ACF), U.S. Department of Health and Human Services, under Contract No. 105-95-1936 to Mathematica Policy Research, Princeton, NJ, and Columbia University's National Center for Children and Families, Teachers College, in conjunction with the Early Head Start Research Consortium. The consortium consists of representatives from 17 programs participating in the evaluation, 15 local research teams, the evaluation contractors, and ACF. Research institutions in the consortium (and principal researchers for conducting this research on children through 36 months of age) include ACF (Rachel Chazan-Cohen, Judith Jerald, Esther Kresh, and Helen Raikes); Catholic University of America (Michaela Farber, Harriet Liebow, Nancy Taylor, Elizabeth Timberlake, and Shavaun Wall); Columbia University (Lisa Berlin, Christy Brady-Smith, Jeanne Brooks-Gunn, and Allison Sidle Fuligni); Harvard University (Catherine Ayoub, Barbara Alexander Pan, and Catherine Snow); Iowa State University (Dee Draper, Gayle Luze, Susan McBride, Carla Peterson); Mathematica Policy Research (Kimberly Boller, Jill Constantine, Ellen Eliason Kisker, John M. Love, Diane Paulsell, Christine Ross, Peter Schochet, Susan Sprachman, Louisa Banks Tarullo, Cheri Vogel, and Welmoet van Kammen); Medical University of South Carolina (Richard Faldowski, Gui-Young Hong, and Susan Pickrel); Michigan State University (Hiram Fitzgerald, Tom Reischl, and Rachel Schiffman); New York University (Mark Spellmann and Catherine Tamis-LeMonda); University of Arkansas (Robert Bradley, Richard Clubb, Andrea Hart, Mark Swanson, and Leanne WhitesideMansell); University of California, Los Angeles (Carollee Howes and Claire Hamilton); University of Colorado Health Sciences Center (Robert Emde, Jon Korfmacher, JoAnn Robinson, Paul Spicer, and Norman Watt); University of Kansas (Jane Atwater, Judith Carta; and Jean Ann Summers); University of Missouri-Columbia (Mark Fine, Jean Ispa, and Kathy Thornburg); University of Pittsburgh (Beth Green, Carol McAllister, and Robert McCall); University of Washington School of Education (Eduardo Armijo and Joseph Stowitschek); University of Washington School of Nursing (Kathryn Barnard and Susan Spieker); and Utah State University (Lisa Boyce, Gina Cook, Catherine Callow-Heusser, and Lori Roggman).

The content of this publication does not necessarily reflect the views or policies of the U.S. Department of Health and Human Services, nor does mention of trade names, commercial products, or organizations imply endorsement by the U.S. government.

The authors would like to thank the Radcliffe Institute for bringing us together in January 2006 to work on this paper.

The lead author would also like to thank Eve and Arlo (who are currently in the "Terrific Twos") and Dan Cohen.

\section{REFERENCES}

Abidin, R. (1983). Parenting stress index professional manual. Odessa, Fl: Psychological Assessment Resources. 
Achenbach, T.M., \& Rescorla, L.A. (2000). Manual of ASEBA preschool forms and profiles. Burlington: University of Vermont, Research Center for Children, Youth, \& Families.

Administration for Children and Families. (2002). Making a difference in the lives of children and families: The impacts of Early Head Start programs on infants and toddlers and their families. Washington, DC: U.S. Department of Health and Human Services.

Administration on Children, Youth and Families. (2001). Building their futures: How Early Head Start programs are enhancing the lives of infants and toddlers in low-income families. Washington, DC: Author.

Bayley, N. (1993). Bayley scales of infant development: Manual (2nd ed.). New York: Psychological Corporation, Harcourt Brace \& Company.

Beardslee, W.R., \& Knitzer, J. (2003). Strengths-based family mental health services: A family systems approach. In K. Maton, C. Schellenbach, B. Leadbeater, \& A. Solarz (Eds.), Investing in children, youth, families, and communities: Strengths-based research and policy (pp. 157-171). Washington, DC: American Psychological Association.

Beardslee, W., Versage, E., \& Gladstone, T. (1998). Children of affectively ill parents: A review of the past 10 years. Journal of the American Academy of Child and Adolescent Psychiatry, 37(11), $1134-1141$.

Belsky, J. (1984). The determinants of parenting: A process model. Child Development, 55, 83-96.

Caldwell, B.M., \& Bradley, R.H. (1984). Home observation for measurement of the environment: Administration manual (Rev. ed.). Unpublished manuscript. Little Rock: University of Arkansas at Little Rock.

Cutrona, C.E., \& Troutman, B.R. (1986). Social support, infant temperament, and parenting selfefficacy: A mediational model of postpartum depression. Child Development, 57(6), 1507-1518.

Dunn, L.M., \& Dunn, L.M. (1997). Peabody Picture Vocabulary Test, 3rd ed. Circle Pines, MN: American Guidance Service.

Elgar, F.J., McGrath, P.J., Waschbusch, D.A., Stewart, S.H., \& Curtis, L.J. (2004). Mutual influences on maternal depression and child adjustment problems. Clinical Psychology Review, 24(4), 441-459.

Fenson, L., Pethick, S., Renda, C., Cox, J.L., Dale, P.S., \& Reznick, J.S. (2000). Short-form versions of the MacArthur Communicative Development Inventories. Applied Psycholinguistics, 21, 95-116.

Fuligni, A.S., Han, W., \& Brooks-Gunn, J. (2004). The infant-toddler HOME in the 2nd and 3rd years of life. Parenting: Science and Practice, 4, 139-159.

Garstein, M.A., \& Sheeber, L. (2004). Child behavior problems and maternal symptoms of depression: A mediational model. Journal of Child and Adolescent Psychiatric Nursing, 17(4), 141-150.

Gelfand, D.M., Teti, D.M., \& Fox, C.R. (1992). Source of parenting stress for depressed and nondepressed mothers of infants. Journal of Clinical Child Psychology, 21(3), 262-272.

Gladstone, T.R.G., \& Beardslee, W.R. (2002). Treatment, intervention, and prevention with children of depressed parents: A developmental perspective. In S.H. Goodman \& I. H. Gotlib (Eds.), Children of depressed parents: Mechanisms of risk and implications for treatment (pp. 277-305). Washington, DC: American Psychological Association.

Goodman, S.H., \& Gotlib, I.H. (1999). Risk for psychopathology in the children of depressed mothers: A developmental model for understanding mechanisms of transmission. Psychological Review, 106(3), 458-490.

Granic, I., \& Patterson, G.R. (2006). Toward a comprehensive model of antisocial development: A dynamic systems approach. Psychological Review, 113(1), 101-131.

Greenberg, M.T., Domitrovich, C., \& Bumbarger, B. (2001). The prevention of mental disorders in school-aged children: Current state of the field. Prevention and Treatment, 4, article 1. Retrieved May 10, 2006, from http://journals.apa.org/prevention/volume4/pre0040001a.html 
Knitzer, J. (2001). Promoting resilience: Helping young children and parents affected by substance use, domestic violence, and depression in the context of welfare reform (Issue Brief 8). New York: National Center for Children in Poverty.

Liaw, F.R., \& Brooks-Gunn, J. (1994). Cumulative familial risks and low-birth weight children's cognitive and behavioral development. Journal of Clinical Child Psychology, 23, 360-372.

Lieb, R., Isensee, B., Hofler, M., \& Wittchen, H. (2002). Parental major depression and the risk of depression and other mental disorders in offspring. Archives of General Psychiatry, 59, 65-374.

Love, J.M., Kisker, E.E., Raikes, H., Chazan-Cohen, R., Constantine, J., Vogel, C., et al. (2005, April). How Early Head Start participation contributes to school readiness. Paper presented at the Society for Research in Child Development, Atlanta, Georgia.

Moos, R.H., \& Moos, B.S. (1984). Family Environment Scale test and manual. Palo Alto, CA: Consulting Psychologists Press.

NICHD Early Child Care Research Network. (1997). The effects of infant child care on infant-mother attachment security: Results of the NICHD study of early child care. Child Development, 68, 860-879.

Pan, B.A., Rowe, M.L., Singer, J., \& Snow, C.E. (2005). Maternal correlates of toddler vocabulary production in low-income families. Child Development, 76, 763-782.

Patterson, G.R. (2002). The early development of coercive family process. In J.B. Reid, G.R. Patterson, \& J. Snyder (Eds.), Antisocial behavior in children and adolescents: Developmental theories and models for intervention (pp. 25-44). Washington, DC: American Psychological Association.

Pilowsky, D.J., Wickramaratne, P.J., Rush, A.J., Hughes, C.W., Garber, J., Malloy, E., et al. (2006). Children of currently depressed mothers: A STAR*D ancillary study. Journal of Clinical Psychiatry, 67(1), 126-136.

Preacher, K.J., \& Leonardelli, G.J. (2001). Calculation for the Sobel test: An interactive calculation tool for mediation tests. Retrieved January 15, 2006, from http://www.unc.edu/ preacher/sobel/ sobel.htm.

Radloff, L.S. (1977). The CES-D Scale: A self-report depression scale for research in the general population. Applied Psychological Measurement, 1, 385-401.

Ross, C.E., Mirowsky, J., \& Huber, J. (1983). Dividing work, sharing work, and in-between: Marriage patterns and depression. American Sociological Review, 48, 809-823.

Sameroff, A.J., \& MacKenzie, M.J. (2003). Research strategies for capturing transactional models of development: The limits of the possible. Development and Psychopathology, 15(3), 613-640.

Seifer, R., Dickstein, S., \& Sameroff, A.J. (2001). Infant mental health and variability of parental depression symptoms. Journal of the American Academy of Child \& Adolescent Psychiatry, 40(12), 1375-1382.

Sobel, M.E. (1982). Asymptotic intervals for indirect effects in structural equations models. In S. Leinhart (Ed.), Sociological methodology 1982 (pp. 290-312). San Francisco: Jossey-Bass.

Tremblay, R.E., Japel, C., Perusse, D., McDuff, P., Boivin, M., Zoccolillo, M., et al. (1999). The search for the age of "onset" of physical aggression: Rousseau and Bandura revisited. Criminal Behavior and Mental Health, 9, 24-39.

Weissman, M.M., Pilowsky, D.J., Wickramaratne, P.J., Talati, A., Wisniewski, S.R., Fava, M., et al. (2006). Remissions in maternal depression and child psychopathology: A STAR*D child report. Journal of the American Medial Association, 295(12), 1389-1398. 